\title{
PENGEMBANGAN ULAR TANGGA MODIFIKASI (ULTAMOD) UNTUK MENGOPTIMALKAN PERKEMBANGAN ANAK
}

\author{
Muthmainnah, Ika Budi Maryatun, Nur Hayati \\ Universitas Negeri Yogyakarta \\ Email: diwan_nafil@yahoo.co.id
}

\begin{abstract}
Abstrak
Penelitian ini bertujuan untuk mengembangkan permainandan media Ular Tangga Modifikasi (Ultamod) guna mengoptimalkan perkembangan anak usia dini. Penelitian ini mengacu pada model pengembangan Borg \& Gall namun hanya sampai pada tahapan nomor 3 yaitu pengembangan prototipe dengan penilaian validator. Teknik pengumpulan data menggunakan skala dengan instrumen lembar skala dan analisis data menggunakan analisis data kuantitatif. Data kuantitatif kemudian dikonversikan ke data kualitatif dengan rumus persentase untuk mengetahui kualitas produk. Target penelitian ini adalah terciptanya Ultamoddan panduan penggunaannya, yang dapat digunakan sebagai alternatif media pembelajaran di PAUD yang dapat mengembangkan keenam aspek perkembangan anak usia dini, yaitu nilai agama moral, fisik motorik, bahasa, kognitif, sosial emosional dan seni. Berdasarkan hasil uji validator, maka media ular tangga modifikasi dan buku petunjuk penggunaan yang telah dibuat peneliti dinyatakan layak diuji coba lapangan dengan revisi. Hal ini dapat dilihat dari pengujian instrumen oleh validator yang secara keseluruhan uji materi diperoleh hasil 78,57 \% (baik) dan uji media diperoleh hasil $80 \%$ (baik).
\end{abstract}

Kata Kunci: pengembangan, ular tangga modifikasi, anak

\section{THE DEVELOPMENT OF SNAKES AND LADDERS MODIFICATION TO OPTIMIZE CHILD DEVELOPMENT}

\begin{abstract}
This research is aimed at developing the modification of Snake and Ladder to optimize the development of early children. This research refers to the basic developing models of Borg and Gallbut only up to the stage number 3 is the development of a prototype with the assessment of the validator. The technique of collecting data using a scale with scale sheet instruments and data analysis using quantitative data analysis. The quantitative data is then converted in to the qualitaitive data with percentage formula to find the product quality. The target of this research is the existence of modified Snake and Ladder and its guide which ca be used an alternative learning media in PAUD that can nurture the six aspects or scopes of early chldren's developments, namely moral religious value, physical motoric, language, cognitive, social emotional, and art. Based on the assesment validator, the modified Snake and Ladder and the user guide book made by the researchers is stated as eligible for the field testing with some revisions. This can be seen from the instrument testing by the validator experts, which over all the result of material testing is 78, 57 $\%$ (good) and the result of media testing is $80 \%(\mathrm{good})$.
\end{abstract}

Key words: developing, the modification of Snake and Ladder, children 


\section{PENDAHULUAN}

Perkembangan ilmu pengetahuan, teknologi, komunikasi dan informasi mendorong adanya inovasi atau pembaharuan dalam penggunaan produk teknologi untuk mendukung proses pembelajaran. Dalam proses pembelajaran, pendidik diharapkan tidak hanya sekedar menggunakan metode ceramah dan pemberian tugas, namun dituntut dapat memanfaatkan media pembelajaran untuk mencapai tujuan pembelajaran. Media merupakan bagian yang tak terpisahkan dan berkaitan erat dengan proses belajar mengajar. Pemilihan media dapat mempengaruhi proses dan hasil belajar anak. Oleh karena itu, guru perlu cermat dan kreatif dalam memilih serta memanfaatkan media pembelajaran yang akan digunakan untuk membantu meningkatkan minat, pemahaman dan pencapaian hasil belajar anak.

Bobbi DePorter \& Mike Hernacki (1999) yang menyatakan bahwa $10 \%$ informasi diserap dari kegiatan membaca, $20 \%$ dari kegiatan mendengar, $30 \%$ dari kegiatan melihat, $50 \%$ dari kegiatan melihat dan mendengar, $70 \%$ dari pengucapan atau yang dikatakan, dan $90 \%$ dari pengucapan atau yang dikatakan dan tindakan atau yang dilakukan. Dari kedua temuan diatas dapat disimpulkan bahwa pembelajaran pada anak usia dini akan berlangsung lebih efektif apabila dibantu dengan media seperti media visual atau audio visual, dimana anak menyerap informasi dengan melihat dan mendengar. Selain itu, melalui media, anak juga lebih menunjukkan minat, konsentrasi dan perhatian terhadap materi pembelajaran, sehingga mampu menyerap informasi dengan lebih baik.

Pengembangan potensi dan aspek perkembangan anak dapat dilakukan melaluimetode bermain. Anak-anak sangat menyukai permainan karena dunia anak adalah bermain. Melalui kegiatan bermain, anak tidak hanya merasakan senang, namun dapat juga mengasah perkembangannya. Apalagi permainan yang mengguna- kan media yang menarik. Dengan bergerak anak dapat mengasah perkembangan fisik motoriknya sekaligus membuat badan menjadi anak sehat. Aspek bahasa dilatih ketika anak berbincang, berinteraksi dan mengembangkan kosakata saat bermain. Aspek kognitif dikembangkan saat anak memainkan strategi permainan. Ketika anak berinteraksi dengan teman, maka aspek sosial emosional pun dapat diasah melalui permainan. Permainan tidak hanya sekedar dapat digunakan sebagai pengisi waktu luang anak, namun dapat digunakan untuk sarana belajar dan mengoptimalkan aspek perkembangan anak. Dengan bermain, anak sekaligus dapat belajar banyak hal.

Terdapat banyak media yang dapat digunakan dalam permainan, salah satunya yaitu ular tangga. Ular tangga adalah permainan papan untuk anak-anak yang dimainkan oleh 2 orang atau lebih. Dalam wikipedia (http://id.wikipedia.org/wiki/ ular_tangga) dijelaskan bahwa papan permainan dibagi dalam kotak-kotak kecil, dan di beberapa kotak digambar sejumlah "tangga" atau "ular" yang menghubungkannya dengan kotak lain. Permainan ini diciptakan pada tahun 1870. Tidak ada papan permainan standar dalam ular tangga. Setiap orang dapat menciptakan papan sendiri dengan jumlah kotak, ular dan tangga yang berlainan. Setiap pemain mulai dengan bidaknya di kotak pertama (biasanya kotak di sudut kiri bawah) dan secara bergiliran melemparkan dadu. Bidak dijalankan sesuai dengan jumlah mata dadu yang muncul. Bila pemain mendarat di ujung bawah sebuah tangga, mereka dapat langsung pergi ke ujung tangga yang lain. Bila mendarat di kotak dengan ular, mereka harus turun ke kotak di ujung bawah ular. Pemenang adalah pemain pertama yang mencapai kotak terakhir.

Permainan ular tangga yang dimainkan pada umumnya belum memiliki kekhasan. Oleh karena itu peneliti ingin mengem- 
bangkan model ular tangga modifikasi yang dapat membantu mengoptimalkan seluruh perkembangan anak, tidak hanya aspek perkembangan tertentu saja. Media Ular Tangga Modifikasi (Ultamod) diharapkan pembelajaran akan lebih menarik dan menyenangkan, sehingga diharapkan kualitas pembelajaran pun dapat ditingkatkan. Ukuran media ular tangga modifikasi yaitu $30 \mathrm{~cm} \times 30 \mathrm{~cm}$ yang memungkinkan anak langsung menjadi bidak, yang dapat masuk ke dalam kotak ular tangga. Jumlah kotak ular tanggayaitu 28 kotak, yaitu dari huruf a sampai z ditambah 2 kotak untuk kata "mulai" dan "selesai". Selain itu, terdapat juga gambar, kata dan angka. Untuk dadu dibuat dari kain flanel dengan ukuran 14 $\mathrm{cm} \times 14 \mathrm{~cm}$ untuk menyesuaikan ukuran kotak Ultamod. Pengembangan Ultamod ini juga akan disertai dengan buku panduan penggunaan Ultamod.

Media Ultamod dapat digunakan untuk mengoptimalkan berbagai aspek perkembangan. Anak bergerak aktif seperti berjalan maju dan mundur sehingga dapat mengembangkan aspek fisik motorik, huruf atau kata yang ada dalam media ular tangga dapat digunakan untuk mengembangkan aspek bahasa, angka yang ada dalam media ular tangga dapat digunakan untuk mengembangkan aspek kognitif yang mana anak mulai mengenal konsep angka, ketika anak harus antri dalam memainkan ular tangga atau kegiatan mempraktikkan sesuai gambar dapat digunakan untuk mengembangkan aspek sosial emosional. Sementara untuk aspek nilai agama moral dikembangkan dengan menghargai teman dan memulai kegiatan dengan berdo'a. Melalui media ular tangga modifikasi diharapkan membuat pembelajaran lebih menarik dan menyenangkan sekaligus dengan satu media dapat mengoptimalkan keenam aspek perkembangan anak.

Penelitian ini bertujuan untuk menghasilkan produk berupa Ular Tangga Mod- ifikasi (Ultamod) untuk mengoptimalkan perkembangan anak usia dini.Hasil penelitian ini diharapkan bermanfaat bagi pengembangan media pembelajaran, baik secara teoritis maupun praktis. Adapun manfaat teoritis adalah hasil penelitian ini dapat memberikan kejelasan teoritis tentang Ular Tangga Modifikasi (Ultamod) untuk mengoptimalkan perkembangan anak usia dini serta dapat memberikan wawasan berpikir ilmiah kepada berbagai pihak yang berkompeten. Manfaat praktis adalah hasil penelitian ini diharapkan dapat memberikan inspirasi dalam pengembangan Ultamod dan penerapannya dalam pembelajaran di PAUD; serta bagi peneliti selanjutnya: peneliti dapat melakukan penelitian lanjutan atau lainnya terkait dengan media dan metode pembelajaran untuk mengoptimalkan perkembangan anak.

\section{Media Pembelajaran}

Media merupakan salah satu komponen pembelajaran yang memegang peranan penting dalam pencapaian tujuan dan hasil belajar. Media berasal dari bahasa Latin dan merupakan bentuk jamak dari kata medium yang berarti perantara, yaitu perantara sumber pesan (a source) dengan penerima pesan (a receiver) (Arief S Sadiman, 2006: 6). Gagne (Arief S Sadiman: 2006) menyebutkan bahwa media adalah berbagai jenis komponen lingkungan anak yang merangsangnya untuk belajar. Pendapat ini diperkuat oleh Briggs (1970) bahwa media adalah segala alat fisik yang dapat menyajikan pesan serta merangsang anak untuk belajar, misalnya buku, film, kaset, film bingkai dan sebagainya. Salah satu nilai media pembelajaran adalah mengkonkretkan konsep-konsep yang abstrak. Konsep-konsep yang abstrak dapat disampaikan dengan lebih sederhana melalui pemanfaatan media pembelajaran. Pemanfaatan media pembelajaran bukanlah fungsi tambahan, tetapi merupakan fungsi tersendiri untuk membantu pen-

Pengembangan Ular Tangga Modifikasi (Ultamod) untuk Mengoptimalkan Perkembangan Anak 
capaian tujuan dan proses pembelajaran yang efektif. Angkowo dan Kosasih (Musfiqon, 2012: 32), mengungkapkan bahwa salah satu fungsi media pembelajaran adalah sebagai alat bantu pembelajaran yang ikut mempengaruhi situasi, kondisi dan lingkungan belajar dalam rangka mencapai tujuan pembelajaran yang telah diciptakan dan didesain oleh guru.

Pemilihan media pembelajaran merupakan bagian integral dalam penggunaan media pembelajaran. Kesalahan dalam pemilihan media dapat mempengaruhi proses dan hasil pembelajaran. Beberapa hal yang perlu dipertimbangkan terkait dengan pemanfataan media pembelajaran, yaitu media pembelajaran sebaiknya relevan dengan tujuan dan isi pembelajaran; kesesuaian dengan perencanaan pembelajaran di TK yaitu Satuan Kegiatan Mingguan (SKM) dan Satuan Kegiatan Harian (SKH); kesesuaian dengan sasaran belajar, kesesuaian dengan tingkat keterbacaan media artinya memenuhi persyaratan dari segi kejelasan gambar, huruf, warna dan ukuran; objektivitas dalam memilih media; dapat membantu mempercepat proses belajar anak, dan perlunya meletakkan dasar-dasar yang konkret dalam berpikir (Badru Zaman, 2008: 4.23-4.24).

Media pembelajaran merupakan alat bantu proses belajar mengajar yang dapat digunakan untuk menstimulasi pikiran, perasaan, perhatian dan kemampuan atau keterampilan pebelajar, sehingga dapat mendorong terjadinya proses belajar. Menurut Briggs (1977), media pembelajaran yaitu sarana fisik untuk menyampaikan isi/materi pembelajaran seperti buku, film, video dan sebagainya. Pendapat ini diperkuat oleh National Education Associaton yang mengungkapkan bahwa media pembelajaran adalah sarana komunikasi dalam bentuk cetak maupun pandangdengar, termasuk teknologi perangkat keras.

\section{Manfaat Penggunaan Media}

Penggunaan media dalam pembelajaran memiliki alasan yang mendasar, khususnya di PAUD yang mana anakanak masih berada pada tahapan berpikir kongkrit dan memiliki waktu konsentrasi yang pendek.Melalui media, anak-anak memperoleh gambaan riil yang dapat membantu pemahamannya dan menarik minatnya untuk memperhatikan. Kemp, E. J. (1980) menyatakan bahwa media pembelajaran memiliki tiga manfaat, yaitu: memberikan motivasi, menyajikan informasi, dan memberikan instruksi. Selain itu, menurut Nana Sudjana dan Ahmad Rivai (1992: 2), manfaat penggunaan media pembelajaran adalah:

a. membuat kegiatan belajar menjadi lebih menarik untuk anak, sehingga merangsang motivasi anak.

b. memberikan penjelasan tentang topik, sehingga dapat membantu anak untuk menguasai dan mencapai tujuan pembelajaran.

c. memperkaya variasi metode mengajar, sehingga anak tidak akan merasa bosan.

d. memberikan ruang yang besar bagi anak untuk mempelajari materi karena tidak hanya bisa mendengar penjelasan dari guru, tapi juga bisa melakukan kegiatan lain seperti mengamati, berlatih, dan presentasi.

Pendapat yang sama dikemukakan Hamalik (Azhar Arsyad, 2006: 15) bahwa pemanfaatan media pembelajaran dapat membangkitkan keinginan dan minat yang baru, membangkitkan motivasi dan rangsangan kegiatan belajar, dan bahkan membawa pengaruh-pengaruh psikologis terhadap anak. Pemanfaatan media pembelajaran di PAUD juga memungkinkan anak berinteraksi secara langsung dengan lingkungan, memungkinkan adanya keseragaman pengamatan atau persepsi belajar pada masing-masing anak, membangkitkan motivasi belajar, menyajikan informasi secara konsisten dan dapat diulang mau- 
pun disimpan secara konsisten, menyajikan pesan atau informasi belajar serempak bagi seluruh anak, mengatasi keterbatasan waktu dan ruang serta dapat mengontrol arah dan kecepatan belajar anak.

\section{Ragam Media}

Pemilihan media pembelajaran merupakan bagian penting dari pemanfaatan media pembelajaran. Kekeliruan dalam media pembelajaran dapat mempengaruhi keberhasilan proses pembelajaran dan hasil belajar yang dicapai anak. Adapun ragam media pembelajaran adalah media visual (indera penglihatan), audio (indera pendengaran) dan audio visual (indera penglihatan dan pendengaran).

a. Media audio adalah media yang menyampaikan pesan melalui indera pendengaran yang dapat merangsang pikiran, perasaan, perhatian dan kemauan anak untuk mempelajari isi tema. Basuki Wibawa (1991: 25) menjelaskan bahwa pesan yang disampaikan melalui media audio dituangkan dalam lambang-lambang auditif verbal, non verbal maupun kombinasinya. Media audio yang kadangkala digunakan di PAUD adalah kaset senam untuk mengembangkan kemampuan motorik kasar anak. Contoh media audio lainnya adalah tape recorder, pita audio, dan radio.

b. Media visual adalah media yang menyampaikan pesan melalui indera penglihatan. Media ini seringkali digunakan oleh guru di lembaga PAUD dalam rangka membantu anak berpikir konkrit. Pada kegiatan apersepsi dan demonstrasi, guru seringkali memanfaatkan media gambar dan poster untuk memberikan gambaran riil pada anak-anak tentang tugas dan pesan pembelajaran yang disampaikan. Contoh media visual lainnya adalah foto, flash card, gambar seri, peta dan globe. c. Media audio visual adalah media yang menyampaikan pesan melalui indera penglihatan dan pendengaran. Media audio visual memiliki kemampuan untuk mengatasi kekurangan dari media audio dan media visual semata. Guru PAUD seringkali menggunakan CD (Compact Disk), televisi, dan video singkat di internet yang diputar mellaui laptop untuk menyampaikan pesan atau materi pembelajaran pada anak. Contoh media audio visual lainnya adalah film dan video clip. Pemanfaatan media audio visual seperti film dan video sangat disukai anak karena tampilannya lebih menarik dengan adanya gambar bergerak, variasi warna, ragam suara, dan cerita yang menarik.

\section{Pemilihan Media}

Setiap media memiliki karakteristik yang khas, termasuk khas dalam kelebihan dan kelemahan yang dimiliki. Media terdiri dari media jadi dan media rancangan. Media jadi bisa diperoleh di pasaran luas karena umumnya merupakan komoditi perdagangan, seperti CD (Compact Disk), kaset, poster dan sebagainya. Sedangkan media rancangan perlu dirancang dan dipersiapkan secara khusus untuk digunakan dalam proses pembelajaran, seperti membuat APE (Alat Permainan Edukatif). Menurut Ely (Arief S Sadiman, 2006), pemilihan media sebaiknya memperhatikan karakteristik anak, strategi belajar mengajar, organisasi kelompok belajar, alokasi waktu dan sumber, serta prosedur penilaian. Dick dan Carey (1978), juga mengungkapkan bahwa terdapat empat faktor yang perlu dipertimbangkan yaitu ketersediaan sumber (dibeli atau dibuat sendiri), ketersediaan dana, tenaga dan fasilitas, faktor yang menyangkut keluwesan, kepraktisan dan ketahanan media untuk waktu yang lama, dan efektivitas biaya. 


\section{Permainan Ular Tangga}

Ular tangga merupakan permainan yang ditemukan dan dimainkan oleh orang-orang India sejak dahulu kala. Di India populer dengan nama Moksha Patamu yang ditemukan oleh guru spiritual hindu. Permainan ini disebut "leela" dan mencerminkan kesadaran hindu di sekitar kehidupan sehari-hari. Nama lainnya adalah "Tangga Keselamatan" yang lalu dibawa ke Victoria Inggris di mana versi barunya telah dibuat dan diperkenalkan oleh John Jacques di tahun 1892. Masuk ke Amerika oleh seorang pembuat mainan bernama Milton Bradley ditahun 1943 yang diberi nama "Snakesn Ladder" yang artinya "Ular Tangga" (http:/hafismuaddab.wordress. com/2012/05/22/sejarah-permainan-ulartangg/).Permainan ular tangga kemudian menjadi permainan di Indonesia meskipun tidak diketahui kapan munculnya permainan tersebut.

Menurut (http:/id.wikipedia.org/wiki/ ular-tangga), ular tangga adalah permainan papan untuk anak-anak yang dimainkan oleh dua orang atau lebih. Papan permainan dibagi dalam kotakkotak kecil dan di beberapa kotak digambar sejumlah "tangga" atau "ular" yang menghubungkannya dengan kotak lain. Kotak-kotak tertentu berisi gambar yang mengandung pesan atau perbuatan. Ada pesan atau perbuatan baik, dan ada yang buruk. Pesan atau perbuatan baik biasanya diganjar dengan kenaikan ke kotak yang lebih tinggi lewat tangga, sedangkan pesan atau perbuatan yang buruk dihukum dengan penurunkan ke kotak yang lebih rendah melewati ular, sehingga dinamakan ular tangga. Papan permainan ular tangga dapat dimodifikasi menjadi media pembelajaran. Giliran bermain dan jumlah langkah yang akan dimainkan ditentukan menggunakan lemparan dadu.

\section{Media Ular Tangga Modifikasi (Ulta- mod)}

Pada penelitian ini penggunaan media ular tangga modifikasi memiliki perbedaan aturan. Perbedaannya yaitu papan permainan dirancang khusus oleh peneliti dengan ukuran $30 \mathrm{~cm} \times 30 \mathrm{~cm}$ untuk setiap kotak, dengan jumlah kotak 28 yang terdiri dari 1 kotak bertuliskan "mulai", 1 kotak bertuliskan "selesai" dan 26 kotak yang berisi angka dan gambar atau peristiwa emosional yang biasanya dialami anak misalnya saat menelpon, menyanyikan lagu, jatuh dari sepeda, bermain dengan teman, diganggu teman dan sebagainya. Kotak dibuat dari bahan spon yang warnanya menarik, lunak tapi kuat apabila diinjak anak. Bidak yang digunakan adalah anak yang mengikuti permainan ular tangga modifikasi ini.

Permainan ular tangga yang dimainkan pada umumnya belum memiliki kekhasan. Dengan adanya Ultamod, pembelajaran akan lebih menarik, aktif interaktif, dan menyenangkan sehingga diharapkan kualitas pembelajaran dapat ditingkatkan. Media ular tangga modifikasi ini dapat digunakan untuk mengoptimalkan beberapa aspek perkembangan sekaligus. Anak bergerak aktif sehingga dapat mengembangkan aspek fisik motorik, huruf atau kata yang ada dalam media ular tangga dapat digunakan mengembangkan aspek bahasa, angka yang ada dalam media ular tangga dapat digunakan untuk mengembangkan aspek kognitif yang mana anak mulai mengenal konsep angka, ketika anak harus antri dalam memainkan ular tangga atau kegiatan melihat kemudian menceritakan gambar atau peristiwa dapat digunakan untuk mengembangkan aspek sosial emosional. Sementara untuk aspek nilai agama moral dikembangkan dengan menunjukkan perilaku mulia (tidak mengganngu teman yang sedang bermain) dan memulai kegiatan dengan berdoa. 


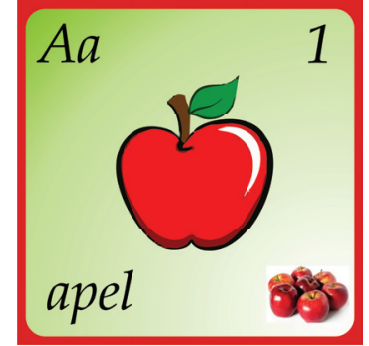

Gambar 1. Contoh Kotak A

Adapun langkah-langkah penggunaan media ular tangga dalam penelitian ini yaitu:

1. Terdapat satu dadu yang digunakan.

2. Semua pemain memulai permainan dari kotak "mulai" dan berakhir pada kotak "selesai".

3. Bidak yang digunakan adalah anak yang bermain ular tangga modifikasi.

4. Terdapat 3 jumlah ular dan 2 tangga pada kotak permainan pada kotak tertentu.

5. Ekor ular mengarahkan bidak pemain untuk mundur sesuai dengan gambar ular, sedangkan gambar tangga mengarahkan bidak pemain maju sesuai dengan gambar tangga.

6. Untuk menentukan giliran pertama yang akan bermain, dilakukan dengan cara hompimpah dan dilanjutkan dengan suit oleh dua pemain yang terakhir.

7. Setelah mengetahui urutan pemain pertama sampai terakhir, para pemain berdiri pada posisi mulai (start) sesuai urutan masing-masing.

8. Pemain pertama melempar dadu dan melangkah di atas kotak sesuai jumlah mata dadu yang keluar.

Pengembangan Ultamod dalam penelitian ini disertai dengan pengembangan buku panduan penggunaan Ultamod agar pengguna dapat lebih mudah dalam memahami langkah-langkah penggunaan dan tepat dalam mempraktikkannya.

\section{METODE \\ Model Pengembangan}

Panduan penggunaan Ultamod untuk mengoptimalkan perkembangan anak dikembangkan berdasarkan model pengembangan produk Borg \& Gall (1983) namun hanya sampai pada tahapan nomor 3 , yaitu pengembangan prototipe dengan uji ahli atau validator media dan materi. Lokasi penelitian ini di TK Masyithoh Kembangsongo Jetis Bantul Yogyakarta.

Pengumpulan data dilakukan dengan skala yang diisi oleh dua validator untuk memberikan masukan pada pengembangan Ultamod. Dalam penelitian ini instrumen pengumpulan data kuantitatif yang digunakan berupa: lembar skala dengan skor 1-4 yang disertai saran dan masukan tertulis.

Teknik analisis data yang digunakan dalam penelitian ini adalah analisis data kuantitatif. Data uji ahli berdasarkan skala penilaian dianalisis secara kuantitatif dengan menggunakan penskoran. Hasil analisis uji ahli digunakan sebagai dasar untuk merevisi media ular tangga yang sesuai bagi perkembangan anak usia dini. Data kuantitatif yang diperoleh melalui penskoran instrumen oleh ahli. Data kuantitatif tersebut kemudian dikonversikan ke data kualitatif dengan rumus persentase untuk mengetahui kualitas produk. Konversi yang dilakukan terhadap data mengacu pada pendapat Suharsimi Arikunto (2006) sebagai berikut.

Tabel 1. Kriteria Penilaian Media Ular Tangga Modifikasi

\begin{tabular}{cll}
\hline No. & Kriteria & Persentase \\
\hline 1. & Sangat Baik & $86 \%-100 \%$ \\
2. & Baik & $71 \%-85 \%$ \\
3. & Cukup & $56 \%-70 \%$ \\
4. & Tidak Baik & $<40 \%$ \\
\hline
\end{tabular}

\section{Pembahasan}

Penelitian ini terdiri dari berbagai rangkaian kegiatan diantaranya yaitu 
melakukan studi literatur dan identifikasi kebutuhan untuk pelaksanaan pengembangan media Ular Tangga Modifikasi (Ultamod) untuk mengoptimalkan perkembangan anak. Kegiatan ini dilakukan dengan cara literatur eksploratorik yang dilakukan dengan mengkaji berbagai teori media dan metode pembelajaran anak TK. Wawancara awal dilakukan dengan guru dan kepala sekolah TK Masyithoh Kembangsongo untuk mengetahui penggunaan media dan metode pembelajaran yang selama ini sudah digunakan di TK. Berdasarkan hasil wawancara diperolehinformasi bahwa metode permainan kadangkala dilakukan meskipun termasuk dalam kategori jarang, sedangkan media pembelajaran umumnya didominasi menggunakan papan tulis, kapur, kertas LKA (Lembar Kerja Anak), crayon, spidol, gunting, lem, dan buku cerita. Untuk media pembelajaran khususnya ular tangga belum pernah digunakan di TK.

Pengembangan media Ultamod ini telah diuji oleh dua validator, yaitu ahli media dan ahli materi yang keduanya merupakan dosen Pendidikan Anak Usia Dini. Berdasarkan penilaian dari kedua validator, maka media yang telah dibuat peneliti dinyatakan layak diuji coba lapangan dengan revisi. Hal ini dapat dilihat dari pengujian instrumen oleh validator dari ahli materi yang menunjukkan bahwa dari 7 indikator draft panduan yang dinilai oleh validator dapat disimpulkan bahwa 6 indikator $(85,7 \%)$ dinyatakan baik, dan 1 indikator (14,2\%) dinyatakan sangat baik. Sedangkan pengujian instrumen oleh validator ahli media menunjukkan bahwa dari 10 indikator draft panduan yang dinilai oleh validator dapat disimpulkan 6 indikator $(60 \%)$ dinyatakan baik, 3 indikator (30 $\%)$ dinyatakan sangat baik dan 1 indikator (10\%) dinyatakan cukup. Secara keseluruhan, apabila data kuantitatif hasil uji materi dikonversikan ke data kualitatif maka diperoleh hasil 78,57\% (Baik) dan hasil uji media diperoleh hasil $80 \%$ (Baik).

\section{Bentuk dan Bahan Ular Tangga Modi- fikasi (Ultamod)}

Penelitian mencoba merancang media ular tangga modifikasi (Ultamod) untuk meningkatkan perkembangan anak. Kekhasan media ular tangga modifikasi ini yaitu ukuran $30 \mathrm{~cm} \times 30 \mathrm{~cm}$ untuk setiap kotak, dengan jumlah kotak 28 yang terdiri dari 1 kotak bertuliskan "mulai", 1 kotak bertuliskan "selesai" dan 26 kotak yang berisi angka 1-26 sekaligus huruf a sampai z. Selain itu terdapat gambar di tengah, dan gambar di kanan bawah sebagai penugasan agar anak mempraktikkan sesuai gambar. Kotak dibuat dari bahan spon yang warnanya menarik, lunak tapi kuat apabila diinjak anak. Gambar ditempelkan pada kotak dengan lem yang kuat sehingga tidak mudah mengelupas. Kotak ular tangga dilengkapi dengan dadu yang berukuran $14 \mathrm{~cm} \times 14 \mathrm{~cm}$.

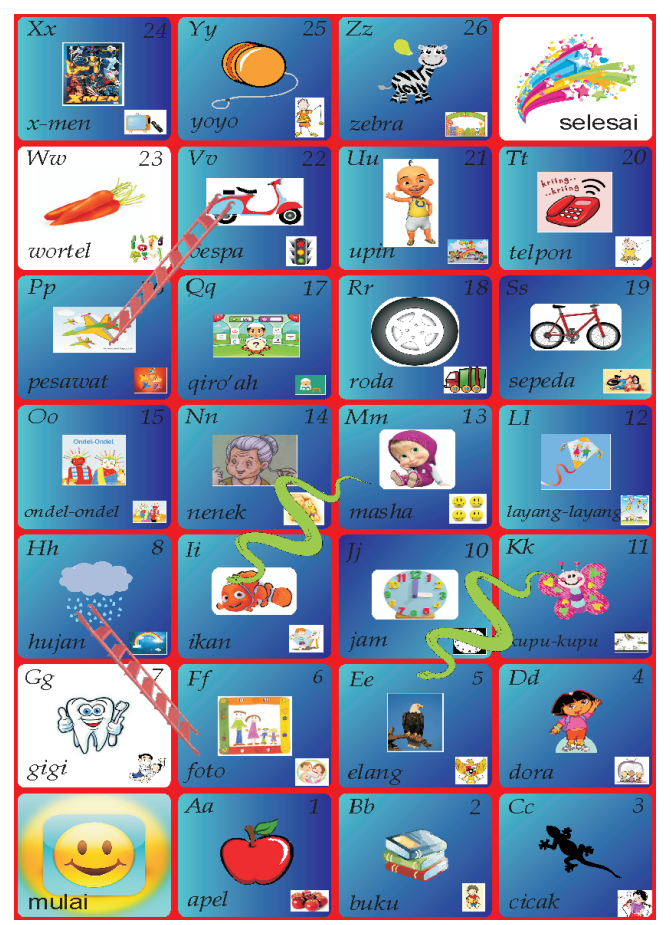

Gambar 2. Bentuk Ultamod dari huruf a sampai z

\section{Panduan Permainan}

Panduan permainan berisi tentang petunjuk penggunaan, aturan umum, aturan 
khusus, keterangan isi kotak ular tangga dan alternatif penugasannya.

Media ular tangga modifikasi ini diharapkan dapat menjadi salah satu alat penyampai materi kepada anak, sekaligus pembawa informasi atau pesan pembelajaran kepada peserta didik. Dengan adanya media ular tangga, pembelajaran akan lebih menarik, aktif interaktif, dan menyenangkan sehingga diharapkan kualitas pembelajaran dapat ditingkatkan. Hal ini sesuai dengan pendapat Nana Sudjana dan Ahmad Rivai (1992: 2) yang menjelaskan bahwa manfaat penggunaan media pembelajaran adalah membuat kegiatan belajar menjadi lebih menarik untuk anak, sehingga merangsang motivasi anak.

Media ular tangga modifikasi ini merupakan salah satu media visual yang dapat digunakan untuk mengoptimalkan beberapa aspek perkembangan sekaligus, yaitu nilai agama moral, fisik motorik, bahasa, kognitif, sosial emosional, dan seni. Hal ini sesuai dengan tujuan pencapaian perkembangan anak yang ada dalam Kurikulum PAUD 2013, yang meliputi enam aspek perkembangan. Dalam penerapannya, beberapa aspek yang akan dikembangkan dapat disesuaikan dengan indikator yang akan dicapai.

Melalui ular tangga modifikasi menjadikan pembelajaran akan menjadi lebih menarik dan menyenangkan karena anak bergerak aktif sehingga dapat mengembangkan aspek fisik motorik, huruf atau kata yang ada dalam media ular tangga dapat digunakan mengembangkan aspek bahasa, angka yang ada dalam media ular tangga dapat digunakan untuk mengembangkan aspek kognitif yang mana anak mulai mengenal konsep angka, ketika anak harus antri dalam memainkan ular tangga atau kegiatan melihat kemudian menceritakan gambar atau peristiwa dapat digunakan untuk mengembangkan aspek sosial emosional. Sementara untuk aspek nilai agama moral dikembangkan dengan menghargai teman dan memulai kegiatan dengan berdoa. Pengembangan aspek perkembangan anak melalui Ultamod telah sesuai dengan kurikulum Pendidikan Anak Usia Dini 2013 (Depdiknas), yang meliputi enam aspek. Secara lebih rinci, kegiatan pengembangan dalam ultamod yang sesuai dengan kurikulum PAUD meliputi:

\begin{tabular}{|c|c|}
\hline Aspek & Bentuk penugasan/kegiatananak \\
\hline Nilai, agama, moral & $\begin{array}{l}\text { Berdo'a sebelum dan sesudah kegiatan, mengenal perilaku baik } \\
\text { dan sopan, melafalkan doa naik kendaraan, serta menghafal surat } \\
\text { pendek. }\end{array}$ \\
\hline $\begin{array}{l}\text { Fisikmotorik } \\
\text { (kasar dan halus) }\end{array}$ & $\begin{array}{l}\text { Melangkah di kotak ular tangga dengan berjinjit, berdiri dengan } \\
\text { kaki satu, berjalan mundur, menirukan gerakan, melipat, dan } \\
\text { menggambar. }\end{array}$ \\
\hline Kognitif & Menghitung, menyebutkanciri-ciri, dan menunjukkan waktu. \\
\hline Bahasa & $\begin{array}{l}\text { Menyebutkan huruf, membaca permulaan/kata sederhana, } \\
\text { menceritakan, danbermain peran. }\end{array}$ \\
\hline Sosial emosional & $\begin{array}{l}\text { Mau antri/sabar menunggu giliran, menyikapi kejadian, dan } \\
\text { percaya diri tampil di depan teman. }\end{array}$ \\
\hline Seni & Menyanyikanlagu dan melakukan tepuk. \\
\hline
\end{tabular}

Pengembangan Ular Tangga Modifikasi (Ultamod) untuk Mengoptimalkan Perkembangan Anak 
Pembuatan media ular tangga ini juga dapat dimodifikasi sesuai dengan alat dan bahan yang tersedia. Hal ini sesuai dengan pendapat Dick dan Carey (1978) yang menyatakan bahwa faktor yang perlu dipertimbangkan dalam pembuatan media yaitu ketersediaan sumber (dibeli atau dibuat sendiri), kepraktisan dan ketahanan media untuk waktu yang lama. Adapun bentuk penugasan dapat divariasi sesuai dengan kebijakan fasilitator, asalkan sesuai dengan tema gambar. Berikut ini alternatif bentuk penugasan yang dapat dilakukan/ ditunjukkan pemain.

\begin{tabular}{|c|c|c|c|}
\hline \multicolumn{4}{|c|}{ Mulai } \\
\hline A & apel & 1 & $\begin{array}{l}\text { - Menghitung jumlah apel } \\
\text { - Menyebutkan warna, bentuk, dan rasa apel. }\end{array}$ \\
\hline B & buku & 2 & $\begin{array}{l}\text { - Menceritakan hobi membaca buku. } \\
\text { - Menjelaskan kegunaan membaca buku. } \\
\text { - Mempraktekkan sikap yang baik saat membaca buku. } \\
\text { - Menceritakan pengalaman saat membaca buku. }\end{array}$ \\
\hline c & cicak & 3 & $\begin{array}{l}\text { - Menyanyikan lagu "Cicak-cicak di Dinding". } \\
\text { - Gerak dan lagu "Cicak-cicak di Dinding". } \\
\text { - Menyebutkan ciri-ciri cicak. }\end{array}$ \\
\hline d & dora & 4 & $\begin{array}{l}\text { - Menceritakan film yang suka dilihat. } \\
\text { - Menceritakan yang biasanya menemani saat nonton tv. } \\
\text { - Mempraktekkan sikap yang baik saat nonton TV. } \\
\text { Samberitakan sikap saat nonton TV, dekat atau jauh dari layar tv? }\end{array}$ \\
\hline e & elang & 5 & $\begin{array}{l}\text { - Menirukan gerakan burung terbang. } \\
\text { - Menceritakan tentang gambar Garuda Pancasila. } \\
\text { - Gerak dan lagu "Garuda Pancasila". }\end{array}$ \\
\hline $\mathrm{f}$ & foto & 6 & $\begin{array}{l}\text { - Melipat sederhana pigura foto. } \\
\text { - Menceritakan foto keluarga yang ada di rumahnya. } \\
\text { - Menceritakan anggota keluarga yang ada di rumahnya. }\end{array}$ \\
\hline $\mathrm{g}$ & gigi & 7 & $\begin{array}{l}\text { - Menceritakan pengalaman saat ke dokter gigi. } \\
\text { - Menjelaskan cara merawat gigi agar sehat. } \\
\text { - Menunjukkan cara menggosok gigi dengan benar. }\end{array}$ \\
\hline $\mathrm{h}$ & hujan & 8 & $\begin{array}{l}\text { - Menceritakan terjadinya hujan dengan tepuk hujan. } \\
\text { - Menyebutkan warna pelangi. } \\
\text { - Menyanyikan lagu "Bunyi hujan”. } \\
\text { - Menyanyikan lagu "Pelangi". }\end{array}$ \\
\hline i & ikan & 9 & $\begin{array}{l}\text { - } \quad \text { Menggambar ikan. } \\
\text { - } \quad \text { Menceritakan ikan yang ada di rumahnya (kalau ada ). }\end{array}$ \\
\hline $\mathrm{j}$ & jam & 10 & Menunjukkan waktu bangun pagi, berangkat sekolah, dan sebagainya. \\
\hline $\mathrm{k}$ & $\begin{array}{l}\text { kupu- } \\
\text { kupu }\end{array}$ & 11 & $\begin{array}{l}\text { - Menirukan gerakan kupu-kupu terbang. } \\
\text { - Menceritakan terjadinya kupu-kupu dengan tepuk. } \\
\text { - Menyanyikan lagu “Kupu-kupu yang Lucu”. }\end{array}$ \\
\hline 1 & $\begin{array}{l}\text { layang- } \\
\text { layang }\end{array}$ & 12 & $\begin{array}{l}\text { - Melipat bentuk layang-layang sederhana. } \\
\text { - Menceritakan pengalaman saat membuat layang-layang. } \\
\text { - Menceritakan pengalaman saat bermain layang-layang dengan teman. }\end{array}$ \\
\hline $\mathrm{m}$ & masha & 13 & Menunjukkan ekpresi saat Masha senang, sedih, takut, dan kecewa. \\
\hline $\mathrm{n}$ & nenek & 14 & $\begin{array}{l}\text { - Menceritakan tentang nenek. } \\
\text { - Menceritakan pengalaman saat bermain dengan nenek. }\end{array}$ \\
\hline
\end{tabular}




\begin{tabular}{|c|c|c|c|}
\hline o & $\begin{array}{l}\text { ondel- } \\
\text { ondel }\end{array}$ & 15 & $\begin{array}{l}\text { - Menirukan gerakan ondel-ondel. } \\
\text { - } \quad \text { Menceritakan asal ondel-ondel. }\end{array}$ \\
\hline $\mathrm{p}$ & pesawat & 16 & $\begin{array}{l}\text { - Melipat bentuk pesawat sederhana dengan kertas lipat. } \\
\text { - Menirukan gerakan pesawat terbang. }\end{array}$ \\
\hline $\mathrm{q}$ & qiro'ah & 17 & $\begin{array}{l}\text { - Menceritakan kebiasaan mengaji di rumah. } \\
\text { - Menceritakan pengalaman saat mendengarkan atau mengikuti latihan } \\
\text { - Menghafalkan surat-surat pendek. }\end{array}$ \\
\hline $\mathrm{r}$ & roda & 18 & Menghitung jumlah roda truk. \\
\hline $\mathrm{s}$ & sepeda & 19 & $\begin{array}{l}\text { - Menceritakan pengalaman saat jatuh dari sepeda. } \\
\text { - Menirukan gerakan mengayuh sepeda. } \\
\text { - Menyanyikan lagu "naik sepeda". }\end{array}$ \\
\hline $\mathrm{t}$ & telepon & 20 & Bermain peran menerima dan menjawab telepon. \\
\hline $\mathrm{u}$ & upin & 21 & $\begin{array}{l}\text { - } \quad \text { Menceritakan pengalaman saat nonton film "upin dan ipin". } \\
\text { - Menyebutkan ciri khas Upin. } \\
\text { - } \quad \text { Menyebutkan nama-nama teman Upin dan Ipin. } \\
\end{array}$ \\
\hline $\mathrm{v}$ & vespa & 22 & $\begin{array}{l}\text { - Menceritakan pengalaman saat naik kendaraan. } \\
\text { - } \quad \text { Melafalkan doa naik kendaraan. } \\
\text { - } \quad \text { Menjelaskan pentingnya menaati rambu-rambu lalu lintas. } \\
\text { - } \text { Menyebutkan arti } 3 \text { lampu merah. }\end{array}$ \\
\hline$w$ & wortel & 23 & $\begin{array}{l}\text { - Menyebutkan berbagai macam sayuran sehat. } \\
\text { - } \quad \text { Menceritakan sayuran kesukaan. }\end{array}$ \\
\hline$x$ & $x$-men & 24 & $\begin{array}{l}\text { - Menyebutkan film kartun yang biasa dilihat di rumah. } \\
\text { - } \quad \text { Menyebutkan bagian-bagian televisi. }\end{array}$ \\
\hline y & yoyo & 25 & $\begin{array}{l}\text { - Menceritakan tentang pengalaman bermain yoyo. } \\
\text { - } \quad \text { Menirukan gerakan bermain yoyo. }\end{array}$ \\
\hline $\mathrm{z}$ & zebra & 26 & $\begin{array}{l}\text { - Menceritakan pengalaman saaat ke kebun binatang. } \\
\text { - } \quad \text { Menyebutkan ciri-ciri zebra. }\end{array}$ \\
\hline \multicolumn{4}{|c|}{ Akhir } \\
\hline
\end{tabular}

\section{PENUTUP}

Kegiatan pengembangan yang dilakukan meliputi pengembangan prototipe media Ular Tangga Modifikasi (Ultamod) dan buku petunjuk penggunaan media ular tanggga modifikasi untuk mengoptimalkan perkembangan anak. Prototipe media ular tangga berupa 28 kotak dari spon ati yang terdiri dari 1 kotak bertuliskan "mulai", 1 kotak bertuliskan "selesai" dan 26 kotak yang berisi angka dan gambar atau peristiwa emosional yang biasanya dialami anak. Untuk buku petunjuk penggunaan media ular tangga modifikasi berisi pendahuluan, petunjuk penggunaan, aturan umum, aturan khusus, keterangan isi kotak dan alternatif penugasannya serta penutup. Prototipe kemudian divalidasi oleh ahli dan pengguna yang hasilnya menyatakan bahwa prototipe model layak untuk diujicobakan. Secara keseluruhan, apabila data kuantitatif hasil uji materi dikonversikan ke data kualitatif maka diperoleh hasil 78,57 \% (Baik) dan hasil uji media diperoleh hasil $80 \%$ (Baik).

\section{DAFTAR PUSTAKA}

Arief S Sadiman dkk. (2006). Media Pendidikan Pengertian, Pengembangan dan Pemanfaatannya. Jakarta: PT Raja Grafindo Persada.

Azhar Arsyad. (2006). Media Pembelajaran. Jakarta: PT Raja Grafindo Persada.

Badru Zaman, Asep Hey H \& Cucu Eliyawati. (2008). Media dan Sumber Belajar TK. Jakarta: Universitas Terbuka. 
Basuki Wibawa \& Farida Mukti. (1991). Media Pengajaran. Jakarta: Depdikbud. Dirjen Dikti.

Bobbi DePorter \& Mike Hernacki. (1999). Quantum Learning. Jakarta: Kaifa.

Borg, W.R \& Gall, M.D. (1983). Educational Research an Introduction. Fourth Edition. New York: Longman Inc.

Departemen Pendidikan Nasional. (2013). Kurikulum 2013. Direktorat Jendral Manajemen Pendidkan Dasar dan Menengah Pembinaan TK SD.

http:/id.wikipedia.org/wiki/ular-tangga diakses tanggal 10 Maret 2015.
Kemp, E. J. (1980). Planning and Producing Audio-Visual Media. New York.

Musfiqon. (2012). Pengembangan Media dan Sumber Pembelajaran. Jakarta: Prestasi Pustakarya.

Nana Sudjana \& Ahmad Rivai. (1992). Media Pengajaran. Bandung: Sinar Baru.

Nana Syaodih Sukmadinata. (2009). Metode Penelitian Pendidikan. Bandung: Rosda Karya.

SuharsimiArikunto. (2006). ProsedurPenelitian. Jakarta: PT RinekaCipta. 